\title{
Insecticidal Effect of Piper guineense Seed Powder in the Control of Beans Weevil Callosobruschus maculatus (Fabr)
}

\section{${ }^{* 1}$ AKHIDENO, LO; ${ }^{1}$ YUSUF, AS; ${ }^{1}$ BAK-POLOR, VR; ${ }^{1}$ ISIBOR, J; ${ }^{1}$ AKEMIEN, NN; ${ }^{2}$ ADAAJA, BO}

\author{
${ }^{* 1}$ College of Forest Resource and Management, Fugar, Edo State, Nigeria \\ ${ }^{2}$ Trial Afforestation Research Station, Afaka, Kaduna, Nigeria \\ *Corresponding Authors' Email: lawsonakhideno@yahoo.com; Tel: +2348060366046
}

\begin{abstract}
Piper guineense commonly called Usira in Edo, Uziza in Igbo and Igherellyere in Yoruba belongs to the family piperaceae. The efficiency of its seed powder in the control of callosobruschus maculatus (beans weevil) was investigated in the Science Laboratory Department of Federal Polytechnic, Auchi, Edo State Nigeria. The seed powder was applied at the rate of $\mathrm{O}$ control, 15, 25, 50 and $100\left(\mathrm{gkg}^{-1}\right)$. The result obtained shows that piper guineense seed powder at $25 \mathrm{gkg}^{-1}$ to $100 \mathrm{gkg}^{-1}$ were effective in the control of callosobrusus maculatus at $0.01 \%$ level of significance. It was revealed that a very strong insecticidal action of I. piper guineense on beans weevil. However, the efficiency of this insecticidal action on callosobruschus maculatus with increasing concentration of the plant material seed powder with $100 \mathrm{gkg}^{-1}$ giving the highest mortality rate, residual action and egg plugs of the weevils. This finding is critical to resource poor farmers in developing countries who will find this trial practicable and affordable.
\end{abstract}

\section{DOI:https://dx.doi.org/10.4314/jasem.v25i5.29}

Copyright: Copyright (C) 2021 Akhideno et al. This is an open access article distributed under the Creative Commons Attribution License (CCL), which permits unrestricted use, distribution, and reproduction in any medium, provided the original work is properly cited.

Dates: Received: 20 March 2021; Revised: 21 April 2021; Accepted: 28 April 2021

Keyword: piper guineense, seed powder, aromatic, beans weevil (callosobrushus maculatus fabr).

Everywhere in the world stored products are attacked by a number of storage enemies. These enemies are group into fungi, insect pests, rat and mice, but the most destructive one is the insect pests (Agrodok, 2004). FAO (1985) reported that insect's pest can damage a considerable part of the stored product. Insect pests need food, air and water to live with. In most cases, stored grains provide a perfect place to live and grow (FAO 1983 Hill, 1987 and Akhideno 2020). Insect pests damage to stored grain results in major economic loss where grains production supports the livelihood of the majority of the population (Jose and Adesina, 2013). Udo, (2000) also reported that insects' pests and many others threaten food security. He also said that post-harvest storage losses to insect pest attack causes $25-100 \%$ damage. With the ever increasing population throughout West Africa especially in Nigeria, satisfying the damage for beans production becomes the basic goal in agricultural production. Beans production is, however, at a high risk as substantial losses that occur due to insect pest infestation, diseases and other harmful organisms during post-harvest storage. Beans losses caused by stored insect pest such as callosobruschus maculatus is a serious issue (Okonkwo, 1998, Onolemhemhem and Oigiengbe 2005 and Akhideno et al, 2015). In their view they reported that insect pest reduces the quality, quantity, nutritive value and viability of the stored grains. Legumes crops especially beans is widely attacked by the grain weevil callosobruschus maculatus causing total losses in storage (Yayaha, 2001). Koehler, (2000) reported that owing to their insidious feeding habits of these inspect pests; they damage the grains very fast. However, owing to the losses resulting from the feeding activities and damage of the beans weevils it is essential that necessary control measured are to be put in place to ensure adequate beans production and storage. Insect pest control in stored food products and field relied heavily on the use of gaseous fumigants and residual contact insecticides which is a serious problem to human health, Ulebor and Onolemhemhem (2001). Murugan (2006) also reported that the European Union has criticized the use of chemicals in the control of insect's pest in stored products, resulting to residual effects to human. Thus, this problem has created the need to find plant materials that will effectively protect field crops and stored products that are readily available, affordable relatively less poisonous and less determinant to the environment.

Piper guineenseis an important ingredient and vegetable oil as primary use for compounding various types of drugs consumed by human beings. In view of this, natural plant species, piper guineenseare much in abundance in the rain forest vegetation and around ourlocalities have some potential in grain preservation, which can be harnessed in the form of powders for use 
in storage (Dike 2001). The achievement in this direction will help to increase the scope of beans production and utilization to meet up with the everincreasing demand for beans products. This trial however aims to determine the efficacy of piper guineense seed powder in the control of callosobruschus maculatus at varied treatment level and to determine the residual effect and seed viability.

\section{MATERIALS AND METHODS}

The experiment was carried out at the Science Laboratory Department of Federal Polytechnic Auchi, Edo State, Nigeria which is located between attitude $6^{0} 45^{1}$ North and longitude $6^{0} 8^{1}$ East with a hot humid tropical climate.

Rearing of Beans Weevil: Adult callosobruschus maculatus obtained from naturally infested beans grain from Auchi Market. These were raised in two kilnerjar containing $200 \mathrm{~g}$ of beans capped with muslin cloth and kept at an ambient temperature of $27^{\circ} \mathrm{c}$ relative humidity of $75-80 \%$. The muslin cloth allow for ventilation but precluded entry or exist of bronchids and other insects.

Plant Material: The fruit of piper guineense were collected from Iruekpen, Esan West Local Government Area of Edo, Nigeria. The fruits were dried to a constant weight of $60^{\circ} \mathrm{c}$ in an Oven. The dry material was grounded to a very fine powder.The beans grains obtained from Auchi market were used. The beans grains were fumigated for 48hours and airated for 7 days, this was to ensure that any developing larva/pupa within the beans grain was killed, as suggested by (Ivbijaro, 1990).The test material piper guineense (powder) was admixed with the beans grain at different rates, $(0,15,25,50$ and $\left.100 \mathrm{gkg}^{-1}\right)$.Similarly, thirty beans weevils made up of 15 male and 15 female was introduced into the treated beans grains and morality court taken. Three replicate for each experiment was set up. All treatments were arranged using the completely randomized design. The following parameters were taken.

Reproductive Capacity: Effects of piper guineense powder on the reproductive capacity of the adults' beans weevils was also investigated 20 days after infestation by treating jars set aside with gentian violent as suggested by (Onolemhemhem and Oigiangbe, 1991) to reveal egg plugs of the weevils. Progeny emergence was recorded from 25 days after infestation till 60 days after infestation.

Mortality: For morality test, the beans grains were treated the test plant material powder at different rates $\left(0,15,25,50,100 \mathrm{gkg}^{-1}\right)$ before the introduction of callosobruschus maculatus. The jar was covered with the muslin cloth, held in place with a rubber band. Morality of callosobruschus maculatus was determined from daily counts for dead adults for 15 days after which all surviving adults were removed as suggested by (Ivbijaro, 1990 and Onolemhemhen and Oigiangbe, 1991).

Residual Effects of the Test Material:The plant material (powder) treated jar was infested with the test beans weevils, 10, 20, 40, 60, 80 and 100days after application. The 30 weevils made up of 15 male and 15 female used morality were used. The reproduction of the test weevils was also studied using the method adopted by (Ivbijaro, 1990).

Seed Viability: This was carried out 0, 30, 60, 90 and 120 days after treatment with powder of the test plant. Twenty seeds at each treatment level were placed in a moistened petri-dishes for 7days. Daily counts of the seed emergence were taken after 5 days and germination means was used to assess beans seed viability.

Data collected were subjected to analysis of variance (ANOVA) using the Genstat release 8.1 statistical software and the means separated using tarkey's test of $1 \%$ level of significance.

\section{RESULTS AND DISCUSSION}

The bio-activities of the residual toxicity of piper guineense seed powder on beans seed viability is presented in table 1 below. The data indicated that at 15 days after treatment had no bad effect on the beans seed viability. There were significant different $(\mathrm{P}<0.001)$ between control $(\mathrm{O})$ and the powder treated seed at rates applied. The control $(\mathrm{O})$ having the lowest viability data value while the $100 \mathrm{~kg}^{-1}$ had the highest viability value. In table 2 below, showing the effect of piper guineense powder on reproductive capacity of callosobruschus maculates in the treatment means as it affected the life cycle of the callosobruschus maculatus. Piper guineense seed powder showed ovicidal effect in the control of the egg plugs of the beans weevil. After treatment, it was observed that the number of emerged adults ranged from $\mathrm{O}$ to 20 , with the control $(\mathrm{O})$ recording the highest number of 20 adults emergence from the egg plugs, while $100 \mathrm{gmkg}^{-}$ ${ }^{1}$ recorded no egg plug.In table 3 below, showed the result of the bio activities of piper guineense seed powder on beans weevil mortality. Data indicate that the piper guineense powder at rates applied caused morality of callosobruschus maculatus adults depending on the length of exposure to the test plant materials. All $24 \mathrm{hrs}$ after infestation, the test plant 
powder caused morality which ranged from 0.00 to 7.20 with $100 \mathrm{mgkg}^{-1}$ treated seeds recorded the highest morality value. The difference between the treatment means were significant $(\mathrm{P}<0.001)$. The table 4 below, showing the effect of residual toxicity of piper guineense seed powder on callosobruschus maculatus indicates that there was a significant difference at
$(\mathrm{P}<0.01)$ among the treatment test with $100 \mathrm{gmkg}^{-1}$ recorded the highest mortality value while the control $\left(0 \mathrm{gkg}^{-1}\right)$ recorded the lowest value. Thus piper guineense seed powder has some residual effect on the beans weevil causing up to $70 \%$ morality at 60 days after treatment in $50 \mathrm{gmkg}^{-1}-100 \mathrm{gmkg}^{-1}$ treated seeds.

Table 1: Effect of residual toxicity of piper guineense powder in Beans grain viability/Days after treatment.

\begin{tabular}{lllllll}
\hline $\begin{array}{l}\text { No } \\
\text { Seed }\end{array}$ & $\begin{array}{l}\text { Piper } \\
\text { Guineense } \\
\text { Powder }\left(\mathrm{gmk}^{-2}\right)\end{array}$ & 15 & 30 & 60 & 90 & 120 \\
\hline 20 & $17.01^{\mathrm{d}}$ & 0 & $13.61^{\mathrm{d}}$ & $14.00^{\mathrm{d}}$ & $15.03^{\mathrm{d}}$ & $16.32^{\mathrm{d}}$ \\
20 & $17.42^{0}$ & 15 & $14.51^{0}$ & $15.56^{0}$ & $16.54^{\mathrm{c}}$ & $17.03^{\mathrm{b}}$ \\
20 & $17.58^{0}$ & 25 & $15.67^{\mathrm{b}}$ & $16.00^{\mathrm{b}}$ & $17.23^{\mathrm{b}}$ & $17.33^{\mathrm{b}}$ \\
20 & $18.72^{\mathrm{b}}$ & 50 & $17.20^{\mathrm{b}}$ & $17.47^{\mathrm{b}}$ & $18.33^{\mathrm{b}}$ & $18.00^{0}$ \\
20 & $22.00^{\mathrm{a}}$ & 100 & $22.00^{\mathrm{a}}$ & $22.00^{\mathrm{a}}$ & $22.00^{\mathrm{a}}$ & $22.00^{\mathrm{a}}$ \\
Means & & 0.38 & 1.25 & 0.99 & 1.04 & 0.63 \\
LSD & & & & & & \\
CV\% & 2.71 & 3.81 & 2.92 & 3.00 & 1.80 &
\end{tabular}

Means followed by the same letter with a column are not significantly different of $1 \%$ level ( $P>0.001)$ Ducan's multiple range.

Table 2: Effect of piper guineense seeds powder in the reproductive capacity of callosobruschus maculates

\begin{tabular}{llll}
\hline $\begin{array}{l}\text { Piper guineense Seed } \\
\text { powder gmkg }{ }^{-1}\end{array}$ & $\begin{array}{l}\text { No of egg } \\
\text { Plugs }\end{array}$ & $\begin{array}{l}\text { No of emergent } \\
\text { Adults }\end{array}$ & $\begin{array}{l}\text { Length of the } \\
\text { life cycle }\end{array}$ \\
\hline 0 & 23 & 20 & $34.00^{0}$ \\
15 & 18 & 8 & $40.00^{\mathrm{b}}$ \\
25 & 8 & 2 & $43.00^{\mathrm{b}}$ \\
50 & 0 & 0 & $0.00^{\mathrm{a}}$ \\
100 & 0 & 0 & $0.00^{\mathrm{a}}$ \\
Means & & & 23.8 \\
LSD & & & 4.49 \\
CV\% & & 5.00 \\
\hline
\end{tabular}

Means, followed by the same letters within a column are not significantly different at $1 \%(P>0.001)$ by Ducan's multiple range test.

Table 3: Effect of piper guineense seeds powder on the morality of callosobruschus maculatus Piper guineense

\begin{tabular}{llllll}
\hline $\begin{array}{l}\text { Seed powder } \\
\left(\mathrm{gmkg}^{-1}\right)\end{array}$ & $24 \mathrm{hrs}$ & $48 \mathrm{hrs}$ & $78 \mathrm{hrs}$ & $96 \mathrm{hrs}$ & $120 \mathrm{hrs}$ \\
\hline 0 & $0.00^{\mathrm{d}}$ & $0.00^{\mathrm{d}}$ & $0.62^{\mathrm{c}}$ & $2.33^{\mathrm{d}}$ & $2.20^{\mathrm{d}}$ \\
15 & $2.00^{\mathrm{c}}$ & $3.00^{\mathrm{c}}$ & $4.00^{\mathrm{d}}$ & $7.67^{\mathrm{c}}$ & $8.87^{\mathrm{c}}$ \\
25 & $3.00^{\mathrm{b}}$ & $5.32^{\mathrm{b}}$ & $8.40^{\mathrm{c}}$ & $10.21^{\mathrm{b}}$ & $15.40^{\mathrm{b}}$ \\
50 & $5.67^{\mathrm{a}}$ & $8.91^{\mathrm{a}}$ & $13.61^{\mathrm{a}}$ & $15.50^{\mathrm{b}}$ & $17.42^{\mathrm{b}}$ \\
100 & $7.20^{\mathrm{a}}$ & $9.32^{\mathrm{a}}$ & $15.41^{\mathrm{a}}$ & $17.33^{\mathrm{a}}$ & $19.00^{\mathrm{a}}$ \\
Means & 4.26 & 5.42 & 8.20 & 10.65 & 12.32 \\
LSD & 0.45 & 1.43 & 1.20 & 1.50 & 0.81 \\
CV\% & 6.30 & 13.2 & 6.4 & 5.60 & 2.60 \\
\hline
\end{tabular}

Means, followed by the same letters within a column are not significantly different at $1 \%$ level $(P>0.001)$ by Ducan's multiple range test.

Table 4: Effect of residual toxicity of piper guineense seed powder on adult callosobruschus maculatus Piper guineense

\begin{tabular}{lllllll}
\hline $\begin{array}{l}\text { Seed } \\
\text { powder } \\
\left(\text { gmkg }^{-1)}\right.\end{array}$ & 10 days & 20days & 40 days & 60 days & 80 days & 100 days \\
\hline 0 & $0.00^{\mathrm{d}}$ & $0.47^{\mathrm{c}}$ & $0.00^{\mathrm{c}}$ & $0.23^{\mathrm{d}}$ & $0.23^{\mathrm{c}}$ & $0.23^{\mathrm{cd}}$ \\
15 & $2.00^{\mathrm{c}}$ & $6.00^{\mathrm{b}}$ & $0.00^{\mathrm{c}}$ & $4.12^{\mathrm{c}}$ & $2.61^{\mathrm{c}}$ & $1.67^{\mathrm{c}}$ \\
25 & $2.67^{\mathrm{b}}$ & $7.01^{\mathrm{b}}$ & $6.33^{\mathrm{b}}$ & $4.33^{\mathrm{c}}$ & $3.00^{\mathrm{ab}}$ & $3.00^{\mathrm{ab}}$ \\
50 & $3.02^{\mathrm{b}}$ & $12.23^{\mathrm{a}}$ & $10.20^{\mathrm{a}}$ & $6.87^{\mathrm{b}}$ & $6.00^{\mathrm{a}}$ & $6.00^{\mathrm{a}}$ \\
100 & $8.41^{\mathrm{a}}$ & $14.07^{\mathrm{a}}$ & $12.30^{\mathrm{a}}$ & $10.54^{\mathrm{a}}$ & $7.23^{\mathrm{a}}$ & $7.33^{\mathrm{a}}$ \\
Means & 8.41 & 6.63 & 5.40 & 5.13 & 4.07 & 2.40 \\
LSD & 1.21 & 1.01 & 2.33 & 3.53 & 3.01 & 1.23 \\
CV\% & 38.04 & 6.31 & 6.60 & 26.07 & 35.06 & 39.71 \\
\hline
\end{tabular}

Means, followed by the same letters with the column are not significantly different at $1 \%$ level $(P<0.001)$ by Duncan's multiple range test.

Many plant extracts have insecticidal properties which can be used to evaluated against stored product insect pest (Adedire and Ajayi, 2003). Forest tree seeds oil have medicinal and bioactive compounds that is either aromatic or toxic to number of insects at various stages of application, (Huang and Lam and, 2000). Piper guineense seed powder exhibited insecticidal properties that had a great effect on callosobruschus 
maculatus. This insecticidal feature from the plant extracts as aromatic component or essential oil present in the fruit and seeds. This has been validated by scientist (Orwa et al, 2009). The insecticidal functions of the piper guineense powder are supported by the previous reports that extracts from plant have been shown to possess insecticidal properties against insect pest (Ulebor and Onolemhemhem 2001, Yayaha, 2002, Akhideno et al 2017). The powder from piper guineense showed a significant $(\mathrm{P}<0.01)$ effect in the control of the reproductive capacity as shown in table 2. However, the efficacy of this insecticidal action of callosobruschus maculatus increased with increasing concentration of the piper guineense seed powder into $100 \mathrm{~g} . \mathrm{kg}^{-1}$ giving the highest mortality rate, residual action and egg hatchability of $87 \%, 70 \%$ and $0 \%$ respectively. This report is in agreement with (Onolemhemhem and Oigiagbe 1998, Niber, 1994 and Yayaha, 2002) who noted that piper guinueense, vegetable oil, were significant to beans weevil control. The aromatic smell is enough to suffocate the beans weevils resulting in residual killing of the weevils over a period of time thus indicating the very strong insecticidal properties of the test plant. Similarly piper guineense seed powder do not have adverse significant effect $(\mathrm{P}<0.01)$ in the bean seed viability as shown in table 1. This report is in agreement with Udo 2005, stated that plants extracts are safe for use, environment, but are broad spectrum pesticides to control insect pest.

Conclusion: The results obtained from this study indicate that using natural plant extracts as grain protectant in storage insect pest management system is very important. The use of this plant materials used for controlling insect pest of stored products are low to mammalian toxicity, affordable, by our resource poor farmer, not harmful, safe to use, pose no environmental hazard, easy to extract, formulate and use with the skill available. It is however suggested that further trial should be directed towards discovering the active constituent in the test material piper guineense.

\section{REFERENCES}

Adedire, CO and Ajayi, OE (2003): Potential of HuraCrepitan L. (sandbox) seed oil for protection of cowpea from callosobrusehus maculatus F. (Coleoptera Bryehidae) Infestation J. Plant Dis. Protect. 110(6) 602-610.

Akhideno, L O (2020): Repellant Effect of piper guineense powder in the control of Beans weevils Callosobrusehus maculatus F. (FABR). The Nig. J. Agric. For. 7.123 -130.

Akhideno, LO; Adeyemi, TOA; Ogboru, RO; and Owoeye EA, (2017): Toxicity effect of Xylopia aethiopica seed powder in the control of insect pest of maize. Inter. J. Sci. Res. 6: 2319-7064

Dike, MC (2001): Plant materials used for controlling insect pest andstored products in Nigeria. Entomology Society of Nigeria (ESN) Occasional Publication No. 33.

FAO, Post-harvest losses in quality of food grain, (1983). FAO food and nutrition paper 29, FAO, Rome, Italy

FAO, Prevention of post-harvest food losses, 1985. FAO training series 10, FAO, Rome, Italy

Hill, DS (1987): Agricultural Insect Pest of the Tropics and their Control. Cambridge University Press, Cambridge UK.

Huang, Y and Lamend, SH (2000): Bioactivities of essential oil form blletaria cardamomum (L) Maton to sitophilus zeamais. Mostehulsky and triboliumcastaneum (Herbst). J Stored Products Res.36:107-117

Ivbijaro, MF (1990): The Efficiency of Seed Oil of Azadirachtaindica a Jess and piper guineense sehum and Thonn on the control of callosobruschus maculatus F. Insect Sci. its Applica. 11(2):149-152

Jose, AR and Adesina, JM; (2013): Damaged suppression and stored maize infested by maize weevil using Bridellia Micrantha and chasmanthra dependens leave powder. Processing of the $47^{\text {th }}$ Annual Conference of the Agricultural Society of Nigeria Pp 38-40

Koehler, PG (2002): Rice weevil, sitophilus oryzae (Coleoprecacurculionidae). Entomology and Hematology Department, Cooperative Extension Service, Institute of food and Agricultural Science, University of Florida, Gainesville (23) 611

Murugan, K (2006): Bio pesticides as environmentally soft tool for the management of insect mosquito vestors. Int. symp on buocont and biotech. Madurai P. 34

Niber, T.B. (1994): The ability of powders and shurries from ten plantspecies to protect stored grain from athletic by prostephanustruncaus Horn (Coleopteran: Bostrichidea) and sitophilus oryzae L. Coleoptera: Curculionidae) J. Stored Prod. Res 30 (4) 297-301 
Okonkwo, EU (1998): Bibliography, A bibliography of plant materials used for controlling insect pest of stored products in Nigeria. Review of Agricultural Entomology 30pp

Onolemhemhem, PO and Oigiangbe, CN (1991): Biology callosobruschus maculatus (Fabr) on cowpea (Vigna unguiculata) and pigeon pea (cajouns cajan L. Druce) treated with vegetable oil and thriol. Samara. J. Agric. Res. (8) 57-63

Orwa, C; Mutua, A; Kindt, R; Jamnadass, R and Anthony S (2009): Agroforest tree data base. A tree reference and selection guide version 4.0. http/www.worldagroforestry.org/sites/treebs/tree data bases.

The Nigeria vanguard (2018): Effect of Chemicals on stored export beans. Published $12^{\text {th }}$ November, 2018
Udo, I.O. (2000): Efficacy of candle wood, Zanthoxylum Xanthoxyloidelam, for the control of three stored products pests, M. Phil. Thesis, University of Ghana, Legion, Accra SIPP.

Ulebor, A and Onolemhemhem, PO (2001): Laboratory investigation of Xylopia acthiopica and piper guineese seeds powder and oils in the control of sitophilu soryzea M.sc Thesis, Ambrose Alli University Ekpoma 79 Pp.

Yahaya, MA (2002): Effect of wood ash and dry fruit powder of piper guineense on callosobruschus maculatus (fabr). The Bean Sokoto J. Pure. .Appl. Sci. 284-287 